\title{
Health Hazards of Garments Sector in Bangladesh: The Case Studies of Rana Plaza
}

Fatema Tania ${ }^{1}$, Nasrin Sultana ${ }^{2}$

${ }^{1}$ Senior Lecturer, Department of Applied Sociology, ASA University Bangladesh, BANGLADESH

${ }^{2}$ Lecturer, Department of Public Health, ASA University Bangladesh, BANGLADESH

\begin{abstract}
Readymade garments are the most important export item from Bangladesh, yet the working conditions and fire safety records in the factories are often not up to the standard. The sector draws global attention to its quality production and women workers are employed. Worker deaths are not new in Bangladesh, and while they have led to recriminations and some vital changes, fires, and other tragic accidents continue. The safety record of the Bangladesh garment industry is one of the worst in the world. The study analyzed the types and extent of occupational health hazards of the garment workers. This study aims to give an overview of what action needs to be taken by the different actors involved in order to improve the safety of garment factories in Bangladesh, what has been achieved so far both in preventing future tragedies and compensating the victims of previous incidents. Study finding shows that participants in the study reported a lack of consciousness about occupational safety and health issues. They are unaware of their fundamental rights at workplaces.
\end{abstract}

Key words: Working Condition, Fire Safety, Health Hazards, Garments Sector, Accident, Occupational Health Hazards.

\begin{tabular}{|c|c|}
\hline Source of Support: Nil, Conflict of Intere & st: None Declared \\
\hline $\begin{array}{l}\text { How to Cite: Tania F and Sultana N. (2015) Health Hazards of Garments Sector in Bangladesh: The Case Studies of Rana Plaza } \\
\text { of Medical and Biological Research, 2(1), 23-30. }\end{array}$ & \\
\hline $\begin{array}{l}\text { This article is is licensed under a Creative Commons Attribution-NonCommercial } 4.0 \text { International License. } \\
\text { Attribution-NonCommercial (CC BY-NC) license lets others remix, tweak, and build upon work non-commercially, and although the new works must also } \\
\text { acknowledge \& be non-commercial. }\end{array}$ & (c) (1) \& \\
\hline
\end{tabular}

\section{INTRODUCTION}

Every year throughout the world, millions of industrial accidents occur and the world is paying heavily for accidents or injuries in terms of both human suffering and economic losses. Despite some progress, the question of safety at work is still a serious problem. Bangladesh is a developing country. Overpopulation, illiteracy and poverty are three major features of this country. The industrial sector of this country was incorporated into these three major problems. In maximum cases, workers who start to work in industries are unskilled as they were not provided with sufficient training. These raw hands begin to work as unskilled labor and through working in the practical field they become skilled as time goes on. But every year, these workers are experiencing thousands of industrial accidents that lead to different occupational injuries. These injuries have an effect on the national economy as they cause losses of productive hours, skilled manpower, and money as compensation and in addition sufferings to the victims and their families. Perhaps enough attention has not paid in this regard because labor was found cheap here.

\section{METHODOLOGY}

The study followed both quantitative and qualitative methods on the basis of primary and secondary data. Personal information especially health hazards aspects were identified through quantitative methods because qualitative methods was used to know the in-depth information regarding health risk. Data was accumulated from Rana Plaza Savar. Later on, respondents were selected by judgment sampling those who were dangerously injured. The significant statements of the interview were tape recorded by the interviewer that was interpreted in verbatim method. Besides, secondary data were collected from national and international books, articles, newspapers, published and unpublished thesis.

\section{OBJectives}

- To identify the health hazards of garments workers

- To find out the causes of the health hazards of garments workers

- To assess the possibility of reduction of health hazards 


\section{LITERATURE REVIEW}

The gender imbalance in the export garment industries in Bangladesh. It evaluates gender difference in conditions of employment and the work environment, and looked at differences in export-oriented garment industry, other export industries, and non-export industries (Pratima Paul-Majumder and Anwara Begum). The nature of female workers contracts and their terms and conditions, their rights \& restructuring processes of garment industries (Naila Kabeer and Simeen Mahmud). The paper titled "Globalization and Bangladesh-A Discussion on Bangladesh's Garment Industry" was about globalization \& Bangladesh garment industries. How globalization affects the garment industries have been highlighted in this paper, the occupational health hazards in a garment sector. In this study, they were analyzed the types of occupational health risk of the garments workers and at the same time they analyze the relationship between various health hazards and workers age (N Nahar, R N Ali and F Begum). Bangladesh garments industries so unsafe and what is the requirement to improve safety standard in the works environment of garments sector and analyze the international standards for the rights to safe work. These papers also assess the prevention pattern of future tragedies. ("Hazardous workplaces: Making the Bangladesh garments safe")

\section{BACKGROUND OF THE STUDY}

\section{Occupational health hazard}

Occupational health refers to the identification and control of the risks arising from physical, chemical, and other workplace hazards in order to establish and maintain a safe and healthy working environment.

When work was associated with health risk, it may cause occupational disease, is one of the multiple causes of other sickness or may aggravate existing ill-health of non-occupational origin. In developing countries, where work is becoming increasingly mechanized, a number of work processes has been developed that treat workers as tools in production, putting their health and lives at risk.

The most successful economies have demonstrated that workplaces designed according to high-quality principles of occupational health, safety and ergonomics are also the most sustainable and productive. In addition, a healthy economy, high quality of products or services and long-term productivity are difficult to achieve in poor working conditions where workers were exposed to health and safety hazards.

\section{Health risk and garments industry}

In Bangladesh, industrial incidents happen in garments sector, and maximum are fire and structure related. The garments sector contains many hazards and risks to workers, ranging from exposure to noise and dangerous substances, to manual handling and working with dangerous machinery. Each processing stage - from the production of materials to the manufacturing, finishing, coloring and packaging pose risks for workers, and some of these are particularly dangerous for women's health. "Since 1990, over 350 workers have died and some 1500 injuries in the fire related incidents in garments industries in Bangladesh. Till 2000, there were more than hundred fires in industries in Bangladesh."

In BGMEA information, before 23 years 1514 workers died in RMG industrial sector and more than 5000 were injured in different RMG industrial disaster.

"In 2012, Tazreen fashion tragedy 112 was died and 300 were injured and 2013 Rana plaza tragedy was died in 1127 and injured more than 2000 people", (Source: UBINIG).

\section{Major industrial sector in Bangladesh}

After independence Bangladeshi economic sector depended on the agriculture and export depend on only jute related manufacturing products. But the government and some private entrepreneurs tried to establish some industrial zone. At the same time, garments sector increases the export and after 30 tears garments sector is the main manufacturing sector in Bangladesh for the different reason. We know that today Tannery industry, Medicine industry, Ship breaking industry, Ceramic industry, Cement industry and some small industrial sector play a big role to earn foreign currency but only garments sector earn $80 \%$ of them. Now we will see that how garments industry reaches the today's position.

\section{History of garments industries}

In1950 was the beginning of R.M.G in the Western World. In order to control the level of imported RMG products from developing countries into developed countries, the Multi-Fiber Agreement (MFA) was made in 1974. The MFA agreement imposed an export rate 6 percent increase every year from a developing country to a developed country. In the early 
1980s, Bangladesh started receiving investment in the RMG sector. Some Bangladeshis received free training from the Korean Company Daewoo. After these workers had came back to Bangladesh, many of them broke ties with the factory they were working for and started their factory. But most of the RMG entrepreneurs are the genuine patriot and started from grass root level who contributing in boosting of the country economy.

The ready-made garment (RMG) industry of Bangladesh started in the late 1970s and became a prominent player in the economy within a short period. The industry has contributed to export earnings, foreign exchange earnings, employment creation, poverty alleviation and the empowerment of women. The export quota system and the availability of cheap labor are the two most important reasons behind the success of the industry. In the 1980s, the RMG industry of Bangladesh was concentrated mainly in manufacturing and exporting woven products. Since the early 1990s, the knit section of the industry has started to expand. Shirts, T-shirts, trousers, sweaters, and jackets are the main products manufactured and exported by the industry.

The RMG industry is the only multi-billion-dollar manufacturing and export industry in Bangladesh. Because the industry contributed only 0.001 percent to the country's total export earnings in 1976, its share increased to about 75 percent of those earnings in 2005. Bangladesh exported garments worth the equivalent of $\$ 6.9$ billion in 2005 , which was about 2.5 per cent of the global total value ( $\$ 276$ billion) of garment exports. The country's RMG industry grew by more than 15 percent per annum on average during the last 15 years. The foreign exchange earnings and employment generation of the RMG sector have been increasing at double-digit rates from year to year.

Currently, there are more than 4,000 RMG firms in Bangladesh. More than 95 percent of those firms were locally owned with the exception of a few foreign firms located in export processing zones (Gonzales, 2002). The RMG firms are situated mainly in three main cities: the capital city Dhaka, the port city Chittagong, and the industrial city Narayangonj.

\section{BANGLADESH GaRments Industries Condition}

"The ready-made garment sector (RMG) in Bangladesh has become the backbone of the Bangladesh economy, producing around $80 \%$ of the country's exports. It is now the second largest garment exporter in the world, exporting over US $\$ 17$ billion worth of clothing in 2011.

In recent years, the industry has boomed, and the number of factories engaged in garment production has increased rapidly. Bangladesh is now estimated to have between four and five thousand garment factories, ranging from large first tier suppliers to small industrial unit mostly operating as subcontractors to bigger clients.

The industry is characterized by low cost, fast production relying on cheap labor to compete with its competitors. Over four million workers, the majority of whom are young women, are employed in the Bangladesh garment industry and remain the lowest paid garment workers in the world. The lack of alternative employment options combined with widespread poverty mean these women are forced to accept jobs that are poorly paid and carried out in workplaces that fail to adhere to the most basic standards of health and safety.

\section{Rana Plaza Tragedy}

\section{A short introduction to Rana Plaza Tragedy}

On April 24, 2013 Rana Plaza disaster in Dhaka's Savar district did. More than 1,000 people lost their lives and thousands became injured in the building collapse. The majority of those killed or wounded were garment workers, but they represented just a fraction of the hundreds of thousands of people employed in hundreds of factories dotted around the Bangladeshi capital. The building that was cracks a day earlier and was warned to avoid using the building. The shops and the bank on the lower floors immediately closed, but garment workers were told to return the following day, their supervisors was declared that this building is safe to work.

\section{Complance of Rana Plaza Garments Factory}

\section{Fire safety}

Garments and accident are closely related to each other in Bangladesh. Fire accidents in industries are created by unplanned work environment, disorganized workers, electric short circuit, faulty electrical wiring, smoking materials, boiler explosion, kitchen stove and carelessness, fire from existing structure, poor building design and mostly due to the lack of concern of industry-owners. When fire stared the factory, the fire alarm did not work. 


\section{Health safety of the workers}

"Most of the female employees (over 85\% female workers) suffer from malnutrition, ill health, reproductive health problem and various community diseases, which they cannot address with low income. In garment industries, normally maternity leave is for 30 days and maximum 60 days. But Govt. Rule of maternity leave is 04 (Four) months with pay. Pregnant female workers suffer from malnutrition and anemia along with other serious complication."

\section{Emergency exit way}

Only one exit way was tazreen fashion, but it is not enough for 1200 workers. In this reason, a lot of workers died and injured the tragedy. But we find out the extreme information, when the workers tried to go out the factory, in this time the emergency exit way and main gate was stopped.

\section{Working hours}

The international standard of everyday working time is 8 hours (ILO). But in Bangladesh, most of the workers are not know the right technological knowledge, for this reason their wage is very underprivileged. As a result, maximum workers are trying overtime work every day but their discriminated the earnings priority. In tazreen fashion tragedy happens at $6.50 \mathrm{pm}$, when overtime work already started.

\section{Space of two machines}

Three feet space between one machine to another machine, it is internationally accepted. In Bangladesh, Maximum garment factory is not following the rules. The industrial unit set the all machine is very near one to one more, it is one of the main reason for an increase the injury when create the disaster. TF factory was not following the rules.

\section{Case Studies}

01.

Name: Manowara Begum

\section{Age: 23}

\section{Husband name: Badsha Bishwas}

\section{From: Foridpur}

She came on three years ago with her husband in Dhaka. Financial condition of her family was very unfortunate that's way they came to Dhaka. At first she took a job in a garments factory by the help of his cousin. Her husband was injured through in an accident when they lived in a village. When her husband became cure than he also took a job in a garment. Manowara worked as a helper in the garments. According to her, their family was survived as well as through husband and wife income. In that condition, they also provide some money to their laws.

The Rana Plaza Tragedy has been occurred 24th April 2013. Manowara begum has joined as a suing helper in garments that was located in Rana Plaza 3rd floor just three months before. According to her views there were minimum two thousand worker were worked together on 3rd floor where she worked and there was only six toilet for male and six for female and they didn't used 'mask' which was fixed.

According to Manowara, she was not interested to go to the office that day but she had no more alternatives because if she didn't go to the office may be she will be sacked from the job. On that day, when she was working in her workplace suddenly the electricity was gone then the generator was started, in the meantime the building was shaking. There is an important point that is all generators must be placed ground floor according to the building construction rules-regulation.

In Rana Plaza, every in level generator was placed illegally. When the building was shaking Manowara begum didn't understand that what is happening? Then she became senseless. When she has been rescued from the destroyed building, and she was admitted the Anam Medical College and got treatment near about fifteen days. Now day by day she is become a paralyzed and she is not only physical immobilize person but also she is becoming mentally sick person because she is unable to forget this accident and for this tragedy her family become physically, mentally, financially and socially destruct situation. 
02.

Name: Nurul Islam

Age: 30

\section{Fathers name: Kasam Pramanik}

\section{From: Bogra}

He was a worker of 'New Wave Bottoms Ltd' at 'Rana Plaza'2nd floor. He was a cutterman. According to his views working environment of this factory, was comparatively fine. Commonly in this factory worker didn't use the mask but they used just when the owner inspected the industrial unit. But it was mandatory for all workers to use musk.

He was working in the factory for one year seven months. On 23th April, there was a crack and warned to avoid using the building but garments authority didn't focus this severe matter. On 24th April, when he has came to work then he heard that a 'Milad Mahfil' has been arranged centrally, and everything was under the control.

After that Nurul Islam became assure and started own workings. After sometimes, the electricity was gone, and suddenly the building has collapsed. He has been rescued on the evening, and he got for the treatment 14 days Saver Upazilla Health Complex. Till now he is getting therapy from CRP. Now he is getting totally unable to do any work. Now he has no job. He's right side of the body became paralyzed. He is only earning member of his family but before nine months he is totally unemployed for his physical condition. He also depressed to thing about the future.

03.

\section{Akhi Begum}

Age: 35

\section{Garments name: Eather Tex, 5th floor Rana Plaza}

Akhi Begum was working in Rana Plaza 5th floor in Eather Tex garments. She had one child. Her husband divorced her from three years ago, and she had no parents and she is living with an aunt. On accident day, she was worked with colleagues usually. Suddenly she felled something has been burst, and everything became dark and she didn't recognize anything. In this situation, she tried to rescue herself but unable to did. She has been rescued after three days. After this incident, she got treatment from Anam Medical College \& CRP for lengthy time but it is impossible to continue this treatment because she has hugged internal injury. Her uterus has been contaminated because when she stays under this divesting, then dust, sharp material was in inside her uterus. Doctor advised her to surgery and cut off of her uterus. Her left hand also totally paralyzed. But she had no more money to continue this treatment. Her aunt was working as a helping hand in different houses, and her aunt was maintaining their family very hardly. According to Akhi's views " I am living as a death person, I have no future, no hope." and she was socially, mentally, economically and physically depressed.

04.

Name- Abdur Razzak

Age- 32

From - Dinajpur

Father- Aziz Pramanik

\section{Garments name- Eather Tex Ltd}

\section{Education- HSC}

Abdur Razzak was worked in Eather Tex Ltd in 5th floor Rana Plaza. He joined as a 'line quality officer' at Eather Tex Ltd in Rana Plaza in 1st April 2013 and after 23 days he faced the accident. According to Abdur Razzak, on 23 April he heard that the building has cracked, and he was going away the office without any permission of higher authority. He knew from other workers that who were absent in the office yesterday they will be removed from the job. That was the reason he went to the workplace. He never forgets this incident may never be forgetting it.

According to Abdur Razzak - he didn't know that why the generator has placed each floor but that should be located on the ground floor. Abdur Razzak said that when they started work after few moments' electricity has gone 
and then generator was started. In that time, the building was jurking and finally it became collapse, and then he couldn't remember anything.

Abdur Razzak was rescue at evening. He got treatment from CRP, and his right hand has broken. He couldn't do anything by his right hand, and he has other physical injuries. He didn't receive any help without one- month salary.

05.

Name- Hasna Begum

Husband name- Syed Ali Fakir

From - Faridpur

Garments name- - New Wave Style Ltd

Age -25

Hasna's husband was a farmer. They have no agricultural land, but they were a sharecropper. Hasna's husband had an accident, and then they borrow huge money from others. For this reason, they moved to Savar and started their life as a garments worker in Rana Plaza.

Her husband was also doing job in another garment factory in Savar area. After the accident, she became physically and psychologically injured, and her body has got heavy pressure. For this reason always she feels a pain all over the body, and her mental condition was very severe. Always panic bothered her, she couldn't sleep at night.

\section{Analysis of the Case Studies}

On the basis of the cases studies, we can say that there are lots of problem found, such as -

- Building construction - Building code should be followed but in this condition it was not followed.

- In any building, generator should be placed on the ground floor but in this building it was found on the different floor. It's also against the rules.

- In garments, there should be emergency exit route, but it was found in this builds.

- Every garment should have their safety rules, but in those garments there are no such rules or regulation. A crack has been found the day before accident, but owner was not taking any protection. As why no warning or initiative has been taken, and lots of death and damage occurred and many people become immobilize.

- According to case finding, many people become economically, physically, psychologically, mentally and socially immobilize.

- Maximum workers of that building didn't get any compensation from the owners.

- Physical injury is higher in this accidents, like- somebody get cut their legs or hands, some women workers get injured in their uterus who become render inoperative forever.

\section{RECOMMENDATION}

- In the whole country where all the garments building/ Commercial buildings should be maintained the building code. Garments should be placed on commercial building, and all the facilities should be available, like- exit, lift, generator and fire extinguisher.

- Garments should have safety rules as why if any accident occur then garments owner should responsible for all kind of occurrence.

- Compensation and compliance should be strictly maintained by the authority.

- Those workers who become disabling should restore by alternative jobs or any other source of income as they are only earning member of the family.

- Compensation should be in the form of the periodic payment throughout a period of incapacity for the workers. Minimum payments were provided in certain circumstances (e.g. partial injury). 


\section{CONCLUSION}

The Ready Made Garment industry is a key driving force of Bangladesh's economic development: in 2011-12 Bangladesh was the world's second largest exporter of apparel. The human costs of doing business in Bangladesh, as illustrated by the Rana Plaza collapse, combined with poor infrastructure and political instability are the most pressing challenges facing the industry. If Bangladesh is not to lose future investment in such a critical industry, all stakeholders must engage in dialogue together to address supply bottlenecks and rebuild the reputation of the industry by improving working conditions.

\section{REFERENCES}

Ahmed, Ferdous; "Background of History of Bangladesh and Ready-made Garment Industry: Key challenges in the RMG Industry," Middle East Journal of Business; Jan2013, Vol. 8 Issue 1, p33.

Ahmed, N., Nasima, M., \& Alam, N. (2013). Socio-Business Consideration of Garment Workers in Bangladesh: A Statistical Review. ABC Journal Of Advanced Research, 2(2), 8-17. fromhttp://journals.abc.us.org/index.php/abcjar/article/view/4.1

Akhtar S and Shimul AM. 2012. Working Hazards as Indicator of Occupational Stress of Industrial Workers of Bangladesh Asian Business Review, 1, 140-144.

Aktar S, Islam MS and Hossen SM. 2012. Human Resource Management Practices and Firms Performance in Bangladesh: An Empirical Study on Pharmaceutical Industry Asian Business Review, 1, 121-125.

Akter S. 2012. Empowerment: Doctor vs Nurses Asian Business Review, 1, 136-139.

Ali YM, Sarwar JM, Sarker MC, Hossain MS, Kayes MN, Rahman MM and Hainz H. 2014. Core Decompression by Laser Osteoperforation: A Preliminary Report of New and Minimally Invasive Modality for the Treatment of Avascular Necrosis of the Femoral Head Malaysian Journal of Medical and Biological Research, 1, 9-17.

Bangladesh Apparel Factory Collapse: Background, in Brief; Mary Jane Bolle, Specialist in International Trade and Finance, June 14, 2013

Clean Clothes Campaign - Hazardous workplaces: Making the Bangladesh Garment industry safe.

Desita ZT and Mulugeta W. 2014. CT scan Positive Finding Pattern of Head Injury at the University of Gondar Hospital; North West Ethiopia Malaysian Journal of Medical and Biological Research, 1, 64-72.

Feleke, N. (2014). The United Nation's Responsibility to Protect Civilians from Massive Human Rights Violations in Light of the Intervention in the Libyan Crisis in 2011. American Journal Of Trade And Policy, 1(2), Full Thesis. Retrieved from http://journals.abc.us.org/index.php/ajtp/article/view/Feleke

Fire Safety in garments industry: Design matters; The Daily Star; June 2008, Page No. 13.

Garment Industry in Bangladesh, The World Bank, Development Research Group/Poverty Reduction and Economic Management Network, from: http://www.worldbank.org/gender/prr.

Globalization and Bangladesh-A Discussion on Bangladesh's Garment Industry, from: http:/ /www.opendemocracy.net/debates/article- 6-30-1840.

Haque MS, Shahnewaz ST and Siddikee MN.2013. Ethical Implications of Public Relations in Bangladesh: Islamic Perspective Asian Business Review, 2, 37-41.

Hazardous workplaces: Making the Bangladesh Garment industry safe, Clean Clothes Campaigns, November 2012

http:/ /en.wikipedia.org/wiki/Bangladeshi_RMG_Sector

http://en.wikipedia.org/wiki/Disaster\#Natural_disaster

http://en.wikipedia.org/wiki/Health\#Occupational_health

Mohammed Ziaul Haider, Competitiveness of the Bangladesh Ready-made Garment Industry in Major International Markets, AsiaPacific Trade and Investment Review Vol. 3, No. 1, June 2007

N Nahar, R N Ali and F Begum; “Occupational health hazards in the garment sector”; Int. J. BioRes. 1(2): pp 01-06 February, 2010.

Naila Kabeer and Simeen Mahmud, Rags, Riches and Women Workers: Export-oriented Garment Manufacturing in Bangladesh. From http://www.wiego.org/publications/

Occupational health; a manual for primary health care workers

Odumeru JA and Ilesanmi OA. 2014. The Effects of Human Resources Development on Financial Performance of Organisations Asian Business Review, 2, 19-23.

Paul-Majumder, Pratima; Begum, Anwara, the Gender Imbalance in the Export Oriented garment industry in Bangladesh, Vol.1, p44, June 2000

Perera GD, Khatibi A and Navarathna NN. 2012. Relaionship between Employee-Organization Congruence (perceived) and Organizational Commitment in the Sri Lankan Apparel Sector Asian Business Review, 1, 132-135.

S. Akhter, A.F.M. Salahuddin, M. Iqbal, ABMA Malek, N. Jahan; "Health and occupational safety for female workforce of garment industries in Bangladesh", Journal of Mechanical Engineering, Vol.41, No. 1,p-65-70, June 2010 
Sadomba WZ and Zinyemba L. 2014. Socio-cultural Foundations of Caregiver Institutions: Lineage and Community Networks in Zimbabwe's Health Care System. Asian Journal of Humanity, Art and Literature, 1, 169-185.

Saha AK and Mondal KC. 2012. Internal Control Practices of Readymade Garments Sector (Textile Industry) in Bangladesh Asian Business Review, 1, 67-71.

Tadesse T, Hawaz Y and Zewdneh D. 2014. Patterns of Chest Radiographic Findings in Neonates with Respiratory Distress Admitted to the Neonatal Intensive Care Unit in Tikur Anbesa Specialized Hospital Malaysian Journal of Medical and Biological Research, 1, 73-79.

Tinne WS. 2013. Nation Branding: Beautiful Bangladesh Asian Business Review, 2, 31-36.

Uddin S, Rahaman MM and Islam MM. 2012. Private Hospitals in Sylhet City, Bangladesh: An Issue of Service Marketing Asian Business Review, 1, 103-105.

World Health Organization Regional Office for the Eastern Mediterranean Cairo 2001

Zahan, N. (2014). Factors Influencing Women's Reproductive Health. ABC Journal of Advanced Research, 3(2), 38-46. Retrieved from http://journals.abc.us.org/index.php/abcjar/article/view/6.4 